\title{
The contradictory role of humor in international competitiveness and innovativeness
}

\author{
Jialei Yang \\ jialei.yang@oulu.fi | University of Oulu, P.O. Box 8000, FI-90014 Oulu, Finland \\ Pia Hurmelinna-Laukkanen \\ pia.hurmelinna-laukkanen@oulu.fi | University of Oulu \\ Eeva-Liisa Oikarinen \\ eeva-liisa.oikarinen@oulu.fi | University of Oulu
}

\begin{abstract}
This study explores the relationships among the use of different types of humor (affiliative, aggressive, reframing, and coping humor) - both among immediate co-workers ("ingroup"), and with actors external to the firm ("outgroup"), international competitiveness, as well as innovativeness. An exploratory study based on survey data suggests that humor, when connections exist, is negatively related to international competitive potential and performance. Whether or not these negative effects emerge, depends on with whom and which type of humor is used. However, the situation is not straightforward: innovativeness is positively related to international competitiveness, and to innovativeness, humor types relate in different ways, some positive, some negative. Overall, humor seems to play a relevant, but challenging-to-manage role especially in settings where borders - organizational or national-are crossed: Humor that works as a lubricant for innovation processes, does not necessarily work directly in advancing international competitiveness.
\end{abstract}

Keywords. Humor; International competitiveness; Innovativeness; Innovation behavior; Innovation output.

Cite paper as: Yang, J., Hurmelinna-Laukkanen, P., Oikarinen, E., (2019). The contradictory role of humor in international competitiveness and innovativeness, Journal of Innovation Management, www.open-jim.org, 7(2), 78-104. 


\section{Introduction}

International competitiveness at the firm level refers to the capability of a firm to sustainably and profitably satisfy international customer requirements (Cetindamar \& Kilitcioglu, 2013; Chikán, 2008). It can be measured in terms of three aspects: competitive potential (assets/factors, i.e., input), competitive performance (outcome), and management processes (Buckley, Pass, \& Prescott, 1988, 1990; Cetindamar \& Kilitcioglu, 2013), and it can be enhanced in different ways, among which advancing innovativeness has been found highly relevant (Alvarez \& Iske, 2015; Özçelik \& Taymaz, 2004). Relatedly, earlier research has considered innovativeness and international competitiveness not only in terms of their interactions (e.g., Brännback \& Wiklund, 2001; Kafouros, Buckley, Sharp, \& Wang, 2008; Keogh, 1999; Kodama, 2017), but also in terms of the common denominators. In this area, it has been established that relationships - internal and external - are relevant for both innovation and international business (see Alvarez \& Iske, 2015; Ramamoorthy, Flood, Slattery, \& Sardessai, 2005). By managing these relationships, one can find ways to enhance innovation and international processes. Thus, this topic has been interesting to academics and practitioners.

This study turns attention to a specific issue within this realm, acknowledging that in the internal and external relationships - and therefore, in international advancements and innovation processes - humor may become a factor to be reckoned (see Cooper, 2005; Graham, 1995). First, extant research has indicated that humor might have an effect on the competitiveness of companies in the international environment (Buckley et al., 1988, 1990; Cetindamar \& Kilitcioglu, 2013). However, the (direct and indirect) connections between humor and international competitiveness are not self-evident, and existing studies incorporating humor related elements (e.g., in connection to cultures) seem to consider international competitiveness at the national level rather than at the firm level (e.g., Skoric \& Park, 2014). The international competitiveness discourse calls for augmentation. Second, on the other side, humor has been found to bear importance in creativity and innovation activities and processes of firms (Hurmelinna-Laukkanen, Atta-Owusu, \& Oikarinen. 2016; Jones \& Bear, 2018; Lussier, Grégoire, \& Vachon, 2017). However, these findings are not completely conclusive - they often focus on creativity (the front-end of innovation), and they tend to lack connection to international activity.

There is also a challenge in the existing management studies that the majority of humor studies has focused on the positive aspects of humor (e.g. Barroso-Tanoira, 2017; Hassan, Razek, \& Alharbi, 2017), overlooking the potentially negative features (Mesmer-Magnus, Glew, \& Viswesvaran, 2012) and failed humor (Robert \& Wilbanks, 2012). While the "double-edged sword" nature of humor has been acknowledged in the field of business management in general (Malone, 1980), and the misuse of inappropriate humor can produce unfavorable results has been known (Cooper, 2008; Robert \& Wilbanks, 2012), the understanding of humor in relation to the premises and outcomes of innovation and international competitiveness suffers from fragmentation and limitations. In particular, it is not very clear whether humor works in similar ways in different managerial situations, and when humor exactly causes negative or positive effects. Therefore, there exist both academic and practical needs to build up a more comprehensive picture, providing a framework that better explains the role of humor in these processes and activities that set the direction for firm competitiveness. 
Following from this setting, this explorative study investigates how different humor types inside and outside firm's boundaries, premises, and outputs of international competitiveness, and innovativeness are interconnected. It is the first study, to our best knowledge, that explores these links. With the help of this knowledge, it is possible to understand better, how humor could be used strategically to promote competitiveness - instead of unintendedly harming it.

In the following, we first briefly discuss the constructs of interest and their interconnections in the light of existing literature. We then proceed to an empirical and quantitative examination. Finally, the main conclusions are discussed in terms of theoretical contributions to the international business and innovation management research, managerial implications, limitations, and directions for future research.

\section{Theoretical background}

\subsection{Humor types in ingroup and outgroup social settings}

Existing literature on humor suggests that humor takes various conceptualizations with regard to definitions, styles, and uses (Mesmer-Magnus et al., 2012). This study adopts one of the most widely accepted definitions of humor in the business management literature given by MesmerMagnus et al. (2012), defining humor as amusing communication shared between two or more actors. Rather than regarding humor as a key interpersonal resource (e.g. Cooper, Kong, \& Crossley, 2018), this study assumes generally that humor works as a mechanism that triggers different emotions. Furthermore, we treat humor as a two-dimensional concept, following Martin, Puhlik-Doris, Larsen, Gray, and Weir (2003): (1) humor (as a form of communication) allows the enhancement of oneself in an intra-psychic way or in one's interpersonal social relationships, and (2) humor has the nature of being either positive or negative.

Based on previous literature (aiming to extend especially the study by Hurmelinna-Laukkanen et al., 2016), this paper groups humor into four types to capture humor's complex and multifaceted nature: affiliative humor, aggressive humor, coping humor, and reframing humor. Affiliative humor refers to relatively harmless and benevolent humor (Martin et al., 2003); aggressive humor refers to humor that intends to condemn, manipulate and put down others under the guise of playful fun (Martin et al., 2003; Romero \& Cruthirds, 2006); coping humor is a mix of so-called liberating and stress relieving humor that distances oneself from experiencing negative stimuli (Lang \& Lee, 2010); and reframing humor refers to humor that addresses things in other ways to inspire new perspectives (Kahn, 1989; Kuiper, McKenzie, \& Belanger, 1995). These categories illustrate how humor can have quite different features and implications - especially when placed in contexts where organizations with varying cultures are interacting (Caloghirou, Kastelli, \& Tsakanikas, 2004).

In fact, the "locus" of humor use can be quite relevant. Earlier literature provides some specific examples on it. When affiliative humor is used in daily activities between co-workers who are members of the same team- "Ingroup"-relationships between co-workers can be enhanced and positive climate in organizations can be built (Romero \& Cruthirds, 2006). Likewise, in this kind of setting, it could be expected that humor can be useful for renewal, since the routines of 
the ingroup can be broken (see Lussier et al., 2017, p. 171 noting that "a lighter atmosphere at work is known to foster collaborative discussions and new problem-solving perspectives"). Mild aggressive humor in an otherwise stable environment can be good for group cohesion (Romero \& Cruthirds, 2006), i.e., the attraction among group members (Kakar, 2018), like coping humor in stressful situations.

On the other hand, when humor is used in interactions with external actors who have a business relationship with the organization (e.g., customers, suppliers, and other stakeholders), it is regarded as being used in the "outgroup" context (see e.g., Lussier et al., 2017). In such a setting - especially if the relationships are not well established, aggressive humor, for example, might have notable adverse effects (Hurmelinna-Laukkanen et al., 2016). Collaboration and knowledge sharing call for norm distance, i.e., "the degree to which the source and recipient of knowledge share the common value system and organizational culture" (Dey \& Mukhopadhyay, 2018, p. 32) to be close enough, but aggressive humor may increase rather than narrow the gap (Romero \& Cruthirds, 2006). Likewise, coping humor could be tricky, if it hits the firm's reputation and image in some ways. Affiliative humor may be useful, if it allows "salespeople [to] become more inclined to provide creative and innovative business solutions to customers", for example (Lussier et al., 2017, p. 171).

At the same time, due to its context-dependency (Mesmer-Magnus et al., 2012), humor could yield quite different influences. In varying firm processes, humor can be useful for intermediate outcomes, while the end result might not be affected (see, e.g., Hurmelinna-Laukkanen et al., 2016 , for differences in premises and outcomes in innovation processes), or vice versa, or the results could be quite opposite in different stages, depending on what factors are observed. While it indicates that having a clear understanding and awareness of the consequences brought by different humor types in a specific business context is managerially meaningful, scholarly information and empirical evidence are relatively scant. It applies especially to international business environments, where complex contexts and cultural differences make it more challenging to understand and predict if specific humor types can be used safely and productively and if there are ones that should be used with caution (or even avoided) (e.g. Cleveland, Laroche, \& Papadopoulos, 2015), and the need for knowledge is even more notable regarding how humor functions in the interaction of innovation and international competitiveness.

\subsection{International competitiveness: competitive potential and competitive perfor- mance}

International competitiveness is a multifaceted concept that has been conceptualized at four levels: product-, firm-, industry-, and national level (Bhawsar \& Chattopadhyay, 2015). Attention is increasingly paid to the firm-level international competitiveness, because it is closely associated with sustainability and success of an entity in international markets (Bhawsar \& Chattopadhyay, 2015).

Previous studies have made efforts to develop measurements of dimensions of international competitiveness (e.g., Buckley et al., 1988, 1990; Cetindamar \& Kilitcioglu, 2013). We decided to focus on two that capture the advancement and realization processes of international competitiveness: competitive potential and competitive performance (Buckley et al., 1988). Competitive potential generates the resources that are used to achieve and improve competitive performance, 
which in turn reflects the outcome of the international activities (Buckley et al., 1988; see also, e.g. Pascucci, 2018). Therefore, we assume that competitive potential contributes to the performance outcomes:

H1. Competitive potential is positively related to competitive performance.

Internal and external relationships and communication are of relevance when considering competitive potential, and competitive performance (e.g. Barnes, Leonidou, Siu, \& Leonidou, 2015; Buckley et al., 1990; Eng, 2005). For example, Kotro and Pantzar (2002) describe how humor as one of the communicative elements allowed Sony to extend the product lifecycle and range in the international markets. However, we are not aware of any empirical or theoretical studies that would consider how different humor types interlink with these dimensions of international competitiveness.

Nevertheless, we can identify some patterns and build some preliminary expectations based on the existing theorization. For example, of the humor types, affiliative humor is considered generally positive, and it is a non-threatening type of humor that enhances social interactions (Romero \& Cruthirds, 2006) and group cohesion (Mesmer-Magnus et al., 2012). However, a negative relationship might emerge between affiliative humor used with ingroup and perceived firm-level competitiveness, if too much humor starts to dilute effectiveness (Romero \& Pescosolido, 2008). Therefore, it could be expected that affiliative humor enhances competitive potential, and further, competitive performance - unless the adverse effects counteract the positive features (for both ingroup and outgroup).

Another expectation relates to aggressive humor. Aggressive humor is intuitively harmful interpersonal humor type with manipulative and putting down features (see Martin et al., 2003; Romero \& Cruthirds, 2006). However, mild aggressive humor might help build cohesive groups (Romero \& Cruthirds, 2006). Therefore, aggressive humor might not be harmful when used between people who know each other well, but when used with the outgroup, it could be riskier (see e.g., Podmetina \& Smirnova, 2013; Tajfel, 1982). In the same line, the dimensions of international competitiveness may also be affected differently, although it is more likely that negative effects emerge (for both potential and performance) if aggressive humor is introduced (in ingroup and outgroup).

As for coping humor and reframing humor (Hurmelinna-Laukkanen et al., 2016), these two types of humor could potentially ease preparation (within ingroup) for entering foreign business environments (i.e., improve competitive potential) and facilitate interactions with parties coming from outside (outgroup) - thereby possibly facilitating business relations and contributing to competitive performance (see Lussier et al., 2017), for example. However, theory (and empirical evidence) are even more silent about these two than other humor types in this context. The role of these four humor types in international competitiveness is in need of more research and empirical examination.

Following these considerations - especially the multiple dimensions and potential contradictions - we take an exploratory approach as we formulate the following hypotheses:

H2a. Different types of humor used with ingroup and outgroup are related to competitive potential. 
H2b. Different types of humor used with ingroup and outgroup are related to competitive performance.

We intend to not only explore the relationships between humor types and international competitiveness, but also go deeper into the complexities in our scrutiny. We believe that insight could be gained from combining innovation research with international competitiveness, especially since international competitiveness is not isolated from innovation activities and processes (Buckley et al., 1990). Among researchers who have examined the topic, Buesa and Molero (1998), for example, suggest that the degree of innovative regularity is positively related to the accumulation of international firm competitiveness, verified by Galende and de la Fuente (2003) and Alvarez and Iske (2015). Kafouros et al. (2008) and Oura, Zilber, and Lopes (2016) also find these kinds of connections. Therefore, it could be that humor relates indirectly to international competitiveness, though having an effect on the dimensions of innovativeness. These dimensions are discussed next.

\subsection{Innovativeness: innovative behavior and innovation output}

Innovation output (Damanpour \& Gopalakrishnan, 1998) in organizations is mainly realized through innovative behavior such as exploring and implementing ideas (Dorenbosch, van Engen, \& Verhagan, 2005; Kesting \& Parm Ulhøi, 2010). Therefore, like international competitiveness, innovativeness can be considered to consist of different elements that connect to each other (Ferreira, Mention, \& Torkkeli, 2015). As earlier studies (e.g. Andries \& Czarnitzki, 2014; Hurmelinna-Laukkanen et al., 2016; Prajogo \& Ahmed, 2006; Scott \& Bruce, 1994) have indicated a tight relationship to exist between innovative behavior and innovation output in organizations, we propose the following hypothesis:

\section{H3. Innovative behavior is positively related to innovation output.}

Furthermore, earlier literature notes that innovative process is influenced by individual and contextual factors such as the interactions between individuals within and outside organizations, and organizational climate (e.g. Barczak, Lassk, \& Mulki, 2010; Bartel \& Garud, 2009; Mcfadzean, 1998; Perry-Smith \& Shalley, 2003; Scott \& Bruce, 1994). In these interactions, and with regard to organizational climate, humor as a form of communication plays different roles. Hurmelinna-Laukkanen et al. (2016) and Lussier et al. (2017) have found that humor can promote both innovative behavior and innovation output, but variation exists. As creativity can be promoted with the use of humor (Hurmelinna-Laukkanen et al., 2016; Lussier et al., 2017), it is likely that the use of varying types of humor - with the exception of aggressive humor (for both ingroup and outgroup) - would promote innovative behavior, the premises of innovation in the process. In this case, the same logic as described above in connection to international potential would apply, except perhaps even more strongly. Reaching better innovation output, however, is a more complicated matter, as suggested by Hurmelinna-Laukkanen et al. (2016). For example, innovative output may be hurt if too much affiliative humor is present (ibid.). Likewise, there are probable differences with regard to ingroup and outgroup contexts. Aggressive humor, in particular, may not be detrimental with ingroup, but with external actors, challenges likely emerge. Following the above-used logic with regard to hypothesis building for the complex relationships when humor types are of concern, we put the relationships examined in Hurmelinna-Laukkanen et al. (2016) in renewed test through the following hypotheses: 
H4a. Different types of humor used with ingroup and outgroup are related to innovative behavior.

H4b. Different types of humor used with ingroup and outgroup are related to innovation output.

In order to develop a research model with a full set of hypotheses, we also investigated the relationships between the dimensions of international competitiveness and innovativeness. It has been suggested that innovation (and more specifically, the whole innovation process more than $\mathrm{R} \& \mathrm{D}$ indicating the potential only) is an important contributor to the competitiveness of firms (see, e.g., Peneder \& Rammer, 2018). Nevertheless, to gain a full view, we draft the following four expectations to constitute Hypothesis 5:

H5a. Innovative behavior is positively related to competitive potential.

H5b. Innovative output is positively related to competitive potential.

H5c. Innovative behavior is positively related to competitive performance.

H5d. Innovative output is positively related to competitive performance.

Figure 1 summarizes and visualizes the hypothesized relations among variables.

In the following chapter, we turn to empirical examination to find out more about the manifold connections described above. We believe that this helps to find patterns for which explanati-

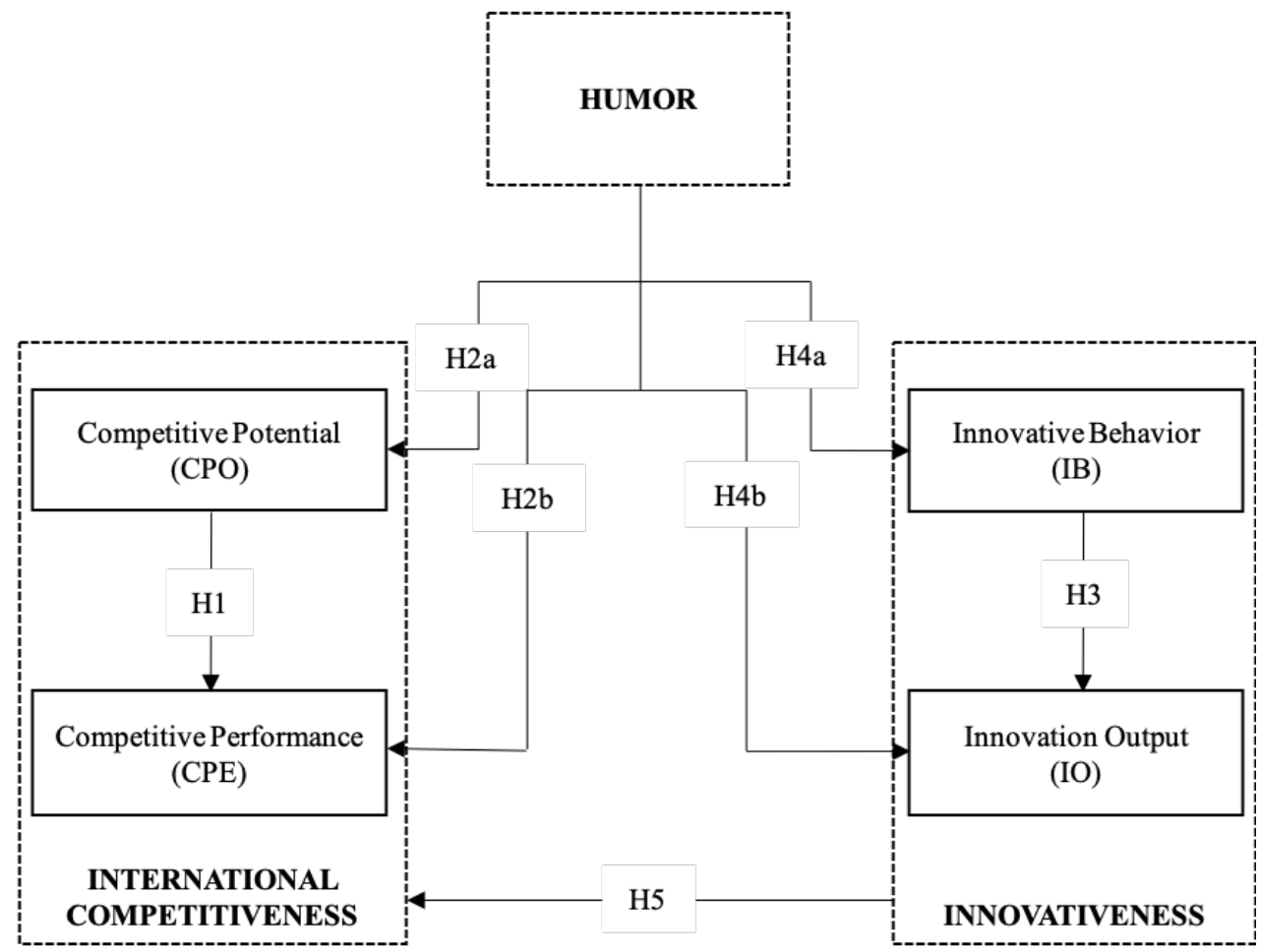

Fig. 1. Research model 
ons can be searched, and that target managerial attention to those processes - especially the potentially contradictory one - where caution is needed.

\section{Methodology}

\subsection{Sample and data}

The data for this study were collected from individuals working in nine organizations using a questionnaire using a five-point Likert scale $(1=$ totally disagree $-5=$ totally agree). The surveyed organizations represent different sectors, including one manufacturing organization, one media company, four organizations in leisure and recreation, and three other services organizations. For the purposes of this study, we distinguish manufacturing and service-oriented organizations, as innovation and international activities of these firms can differ (Hurmelinna-Laukkanen \& Ritala, 2012; Maskus, 2008). For practical reasons, the dissemination of the survey questionnaires within the firms was done by the firm top managers. These organizations participated in a broader research project, meaning that the managers of the companies had incentives to get accurate information on the current situation, and we are relatively certain that they did their best to follow the instructions given by the researchers. To fairly assess the innovative work behavior of respondents, the survey was not restricted to a certain employee category. Eventually, we received 118 usable responses.

During the development and pretesting of the questionnaire, the procedural precautions suggested by Podsakoff, MacKenzie, Lee, and Podsakoff (2003) were followed to minimize the common method bias: the items were designed with established scales, the order of questions was counterbalanced, the independent variables were separated from the dependent ones, and the respondents were assured of confidentiality and anonymity. Furthermore, despite some criticisms of the procedures, Harman's one-factor (or single-factor) test was run at the analysis stage. The test indicates that the common method bias is not a problem, since the first factor accounted for $26 \%$ and $25 \%$ of the variance in humor use with ingroup and humor use with outgroup respectively. A non-response bias test, as suggested by Armstrong and Overton (1977), was also conducted, and it showed that early and late respondents had no significant difference in response. No problems relating to non-response were therefore detected.

\subsection{Measures}

For measure development, factor analysis was conducted first to test latent variables for the eight constructs related to humor types (affiliative/ aggressive/ coping/ reframing humor used in ingroup/ outgroup), international competitiveness (competitive potential and competitive performance) and innovativeness (innovative behavior and innovation output). Then reliability analysis was conducted to check the homogeneity between constructs.

Dependent variables. In order to scrutinize the two innovation process dimensions, innovative behavior was measured by a ten-item scale and innovation output was assessed with a nine-item scale based on the approach developed by de Jong and den Hartog (2010). For international studying advancements of international competitiveness, perceptions on competitive potential were evaluated using a six-item scale developed by Buckley et al. (1988; 1990). Respectively, 
competitive performance level was self-rated by ten items based on the work of Buckley et al. (1988) and Cetindamar and Kilitcioglu (2013) (See Appendix 1).

Independent variables. The four humor types were assessed with a 20 item scale, per Martin et al. (Martin et al., 2003) and Lang and Lee (Lang \& Lee, 2010). Respondents were asked to evaluate humor use both within organizations (ingroup) and outside organizations (outgroup) separately. Five items measured affiliative humor; five items reflected aggressive humor; seven items captured coping humor; and three items comprised reframing humor (see Appendix 1). Especially, innovative behavior, innovation output, and competitive potential were used as independent variables in certain models.

Control variables. Age was controlled for because previous research suggests that older employees are more likely to exhibit higher innovative behavior ( $\mathrm{Ng} \&$ Feldman, 2013). Gender (1 $=$ male, $0=$ female) was also controlled since male and female respondents might be engaged in innovative work and international activities through different approaches (Ohlott, Ruderman, \& Mccauley, 1994). In addition to gender, position $(1=$ managerial position, $0=$ other $)$ was included as leaders might function and perform differently from workers with regard to innovation, and evaluate these activities differently (Unsworth \& Parker, 2003). Tenures (years) in organization and industry were also controlled following the idea by Carmeli and Spreitzer (2009) indicating that working experience might have an influence on innovativeness and the related perceptions on innovation in the organization. Moreover, experienced workers might be more likely to be engaged in international activities (Vance, 2005). Finally, industry (a dummy variable) was used to control the differences that resulted from industry types in international competitiveness and innovativeness (Castellacci, 2008). All variables used in this study and their detailed explanations can be found in Appendix 1.

\subsection{Data analysis and results}

Tables 1 and 2 below show the correlations for humor use in ingroup and outgroup contexts. Innovative behavior and innovation output have a positive relationship with each other, like competitive potential and competitive performance. The correlations between a specific humor type and innovation output exhibit similar relationships as those of humor type and innovative behavior. On the other hand, humor types have different correlations with competitive potential compared to competitive performance.

Following the examination of the correlation matrices, hierarchical regression analyses were used to explore the relationships among the constructs more closely. Prior to this, statistic criteria were checked to assure that there is no violation of underlying assumptions of regression analyses. Most values of the variable inflation factor (VIF) were found to be around 3 and all of them were below the threshold of 10 (see Hair, Anderson, Tathan, \& Black, 1998). This suggests that there is no immediate multicollinearity issue. The scatter plots of the residuals, histograms, and normal probability plots were checked, and they showed normal distributions. The Breusch-Pagan test was also run, showing that heteroscedasticity was not present and that the residuals are normally distributed. Therefore, there is no immediate need to be concerned about heteroscedasticity and nonnormality.

Regression analyses of innovative behavior, innovation output, competitive potential, and competitive performance are reported in Table 3. In the hierarchical regression analyses, control 
Table 1. Correlations for humor use with organization internal actors (ingroup).

\begin{tabular}{|c|c|c|c|c|c|c|c|c|c|c|c|}
\hline Variable & $\begin{array}{l}\text { Mean } \\
\text { (S.D.) }\end{array}$ & 1 & 2 & 3 & 4 & 5 & 6 & 7 & 8 & 9 & 10 \\
\hline 1. Age & $\begin{array}{c}30.39 \\
(12.83)\end{array}$ & & & & & & & & & & \\
\hline $\begin{array}{l}\text { 2. Tenure in } \\
\text { organization }\end{array}$ & $\begin{array}{c}4.17 \\
(2.03)\end{array}$ & $.65^{* *}$ & & & & & & & & & \\
\hline $\begin{array}{l}\text { 3. Tenure in } \\
\text { industry }\end{array}$ & $\begin{array}{c}4.13 \\
(1.93)\end{array}$ & $.62^{* *}$ & $.77^{* *}$ & & & & & & & & \\
\hline $\begin{array}{l}\text { 4. Affiliative } \\
\text { humor }\end{array}$ & $\begin{array}{c}3.61 \\
(0.95)\end{array}$ & -.18 & -.04 & -.02 & & & & & & & \\
\hline $\begin{array}{l}\text { 5. Aggressive } \\
\text { humor }\end{array}$ & $\begin{array}{l}1.59 \\
(.61)\end{array}$ & $.20^{*}$ & -.06 & -.05 & $.30^{* *}$ & & & & & & \\
\hline 6. Coping humor & $\begin{array}{c}3.67 \\
(0.77)\end{array}$ & -.16 & -.03 & -.03 & $.63^{* *}$ & $.36^{* *}$ & & & & & \\
\hline $\begin{array}{l}\text { 7. Reframing } \\
\text { humor }\end{array}$ & $\begin{array}{c}2.41 \\
(1.10)\end{array}$ & .10 & $.21^{*}$ & $.23^{*}$ & $.37^{* *}$ & $.38^{* *}$ & $.51^{* *}$ & & & & \\
\hline $\begin{array}{l}\text { 8. Innovative } \\
\text { behavior }\end{array}$ & $\begin{array}{l}3.05 \\
(.92)\end{array}$ & $.26^{* *}$ & $.21^{*}$ & $.25^{* *}$ & $.27^{* *}$ & .09 & $.20^{*}$ & $.26^{* *}$ & & & \\
\hline $\begin{array}{l}\text { 9. Innovation } \\
\text { output }\end{array}$ & $\begin{array}{c}2.70 \\
(1.32)\end{array}$ & $.22^{*}$ & $.28^{* *}$ & $.31^{* *}$ & .10 & -.06 & $.25^{* *}$ & $.29^{* *}$ & $.50^{* *}$ & & \\
\hline $\begin{array}{l}\text { 10. Competitive } \\
\text { potential }\end{array}$ & $\begin{array}{c}2.59 \\
(1.75)\end{array}$ & .05 & -.08 & -.11 & -.02 & .06 & .20 & 0.21 & .20 & .22 & \\
\hline $\begin{array}{l}\text { 11. Competitive } \\
\text { performance }\end{array}$ & $\begin{array}{c}2.24 \\
(1.59)\end{array}$ & -.05 & -.06 & -.13 & .15 & .20 & .18 & $.25^{*}$ & $.25^{*}$ & .20 & $.78^{* *}$ \\
\hline
\end{tabular}

Notes: ${ }^{*} \mathrm{p}<.05 ;{ }^{* *} \mathrm{p}<.01$ 
Table 2. Correlations for humor use with external actors (outgroup).

\begin{tabular}{|c|c|c|c|c|c|c|c|c|c|c|c|}
\hline Variable & $\begin{array}{l}\text { Mean } \\
\text { (S.D.) }\end{array}$ & 1 & 2 & 3 & 4 & 5 & 6 & 7 & 8 & 9 & 10 \\
\hline 1. Age & $\begin{array}{c}30.39 \\
(12.83)\end{array}$ & & & & & & & & & & \\
\hline $\begin{array}{l}\text { 2. Tenure in } \\
\text { organization }\end{array}$ & $\begin{array}{c}4.17 \\
(2.03)\end{array}$ & $.65^{* *}$ & & & & & & & & & \\
\hline $\begin{array}{l}\text { 3. Tenure in } \\
\text { industry }\end{array}$ & $\begin{array}{c}4.13 \\
(1.93)\end{array}$ & $.62^{* *}$ & $.77^{* *}$ & & & & & & & & \\
\hline $\begin{array}{l}\text { 4. Affiliative } \\
\text { humor }\end{array}$ & $\begin{array}{c}2.71 \\
(1.04)\end{array}$ & .04 & .03 & .09 & & & & & & & \\
\hline $\begin{array}{l}\text { 5. Aggressive } \\
\text { humor }\end{array}$ & $\begin{array}{l}1.26 \\
(.50)\end{array}$ & .02 & .03 & .02 & $.31^{* *}$ & & & & & & \\
\hline 6. Coping humor & $\begin{array}{l}2.73 \\
(.98)\end{array}$ & .14 & .13 & .15 & $.68^{* *}$ & $.42^{* *}$ & & & & & \\
\hline $\begin{array}{l}\text { 7. Reframing } \\
\text { humor }\end{array}$ & $\begin{array}{c}1.60 \\
(1.00)\end{array}$ & $.26^{* *}$ & $.25^{* *}$ & $.30^{* *}$ & $.42^{* *}$ & $.42^{* *}$ & $.68^{* *}$ & & & & \\
\hline $\begin{array}{l}\text { 8. Innovative } \\
\text { behavior }\end{array}$ & $\begin{array}{l}3.05 \\
(.92)\end{array}$ & $.26^{* *}$ & $.21^{*}$ & $.25^{* *}$ & $.33^{* *}$ & -.03 & $.24^{*}$ & $.21^{*}$ & & & \\
\hline $\begin{array}{l}\text { 9. Innovation } \\
\text { output }\end{array}$ & $\begin{array}{r}2.70 \\
(1.32)\end{array}$ & $.22^{*}$ & $.28^{* *}$ & $.31^{* *}$ & $.20^{*}$ & .01 & $.27^{* *}$ & $.23^{*}$ & $.50^{* *}$ & & \\
\hline $\begin{array}{l}\text { 10. Competitive } \\
\text { potential }\end{array}$ & $\begin{array}{r}2.59 \\
(1.75)\end{array}$ & .05 & -.08 & -.11 & .07 & -.09 & $.24^{*}$ & .20 & .20 & .22 & \\
\hline $\begin{array}{l}\text { 11. Competitive } \\
\text { performance }\end{array}$ & $\begin{array}{r}2.24 \\
(1.59)\end{array}$ & -.05 & -.06 & -.13 & .09 & .04 & .21 & .21 & $.25^{*}$ & .20 & $.78^{* *}$ \\
\hline
\end{tabular}

Notes: ${ }^{*} \mathrm{p}<.05 ;{ }^{* *} \mathrm{p}<.01$ 
variables were entered first before adding the main constructs. Proceeding with the testing, such constructs that were found significant in the preceding models were also included in the subsequent models. For example, Model 6, which tests humor types used with ingroup against innovative output, includes also innovative behavior, that was found to be related to innovative output in the earlier Model 5.

The hierarchical regressions were conducted as follows. To test for the relationship between innovative behavior and different humor types, the hierarchy consisted of two steps: (a) control variables (Table 3, Model 1), and (b) four types of humor used with ingroup (Model 2) and outgroup (Model 3). The regression results show that only one type of humor - affiliative humor - is significantly related to innovative behavior, thus Hypothesis 4a receives partial support. This applies to both ingroup and outgroup. Similarly, in the regressions with innovation output as the dependent variable, control variables were added first (Model 4) and then innovative behavior was entered (Model 5). The findings suggest that innovative behavior is positively related to innovation output, thereby supporting Hypothesis 3. Four humor types used with ingroup and outgroup were further added, constituting Models 6 and 7. Partial support is found for Hypotheses 4b: Humor types and innovation output seem to be related only when humor is used in the ingroup context, taking into account the effect of innovative behavior. Affiliative and aggressive types of humor are negatively related to innovation output, while coping humor shows a positive relationship.

For the competitive potential analysis, innovative behavior was added (Model 9) subsequent to entering control variables (Model 8). However, no significant relationship was found. Therefore, no support was rendered to Hypothesis 5a. After replacing innovative behavior with innovation output as the second level of hierarchy (Model 10), a significantly positive relationship between innovation output and competitive potential was detected, which supports Hypothesis 5b. Humor was entered third (ingroup: Model 11; outgroup: Model 12). Partial support is found for Hypotheses $2 \mathrm{a}$ and $2 \mathrm{~b}$, as the results indicate that only specific humor types are significantly - and negatively - related to competitive potential (affiliative humor in ingroup, and aggressive humor in outgroup context) and to competitive performance (coping humor in ingroup). Moreover, humor explains competitive potential more than innovation output (when comparing Model 10 with Models 11 and 12).

The rest of the models (Models 13 to 19) analyzed the relationship between competitive performance and other variables. Levels constructing the hierarchy of the first four regression models are (1) control variables (Model 13), (2) innovative behavior (Model 14), innovation output (Model 15) and competitive potential (Model 16). The results indicate a positive relationship between innovative behavior and competitive performance (Model 14) (supporting Hypothesis 5c), between innovative output and competitive performance (Model 15) (supporting Hypothesis $5 \mathrm{~d}$ ), and between competitive potential and competitive performance (Model 16) (supporting Hypothesis 1). These findings were controlled as a set in the following tests, constituting the first level of the hierarchy of the remaining three regression models (see Model 17) where humor was added (ingroup: Model 18; outgroup: Model 19). According to Model 18, coping humor used with ingroup is found to be negatively related to international competitive performance, but no other relationships can be detected. 
Results are summarized in Table 3, and findings are discussed in more detail in the next section.

\section{Discussion}

The objective of this paper was to explore the connections among humor, innovativeness, and international competitiveness. Considering the complexity of the setting, we drafted general hypotheses on the relationships and examined the empirical evidence on them. The empirical findings are visually summarized in Figure 2, and further details on humor types and their "locations" in ingroup or outgroup are illustrated in Table 4.

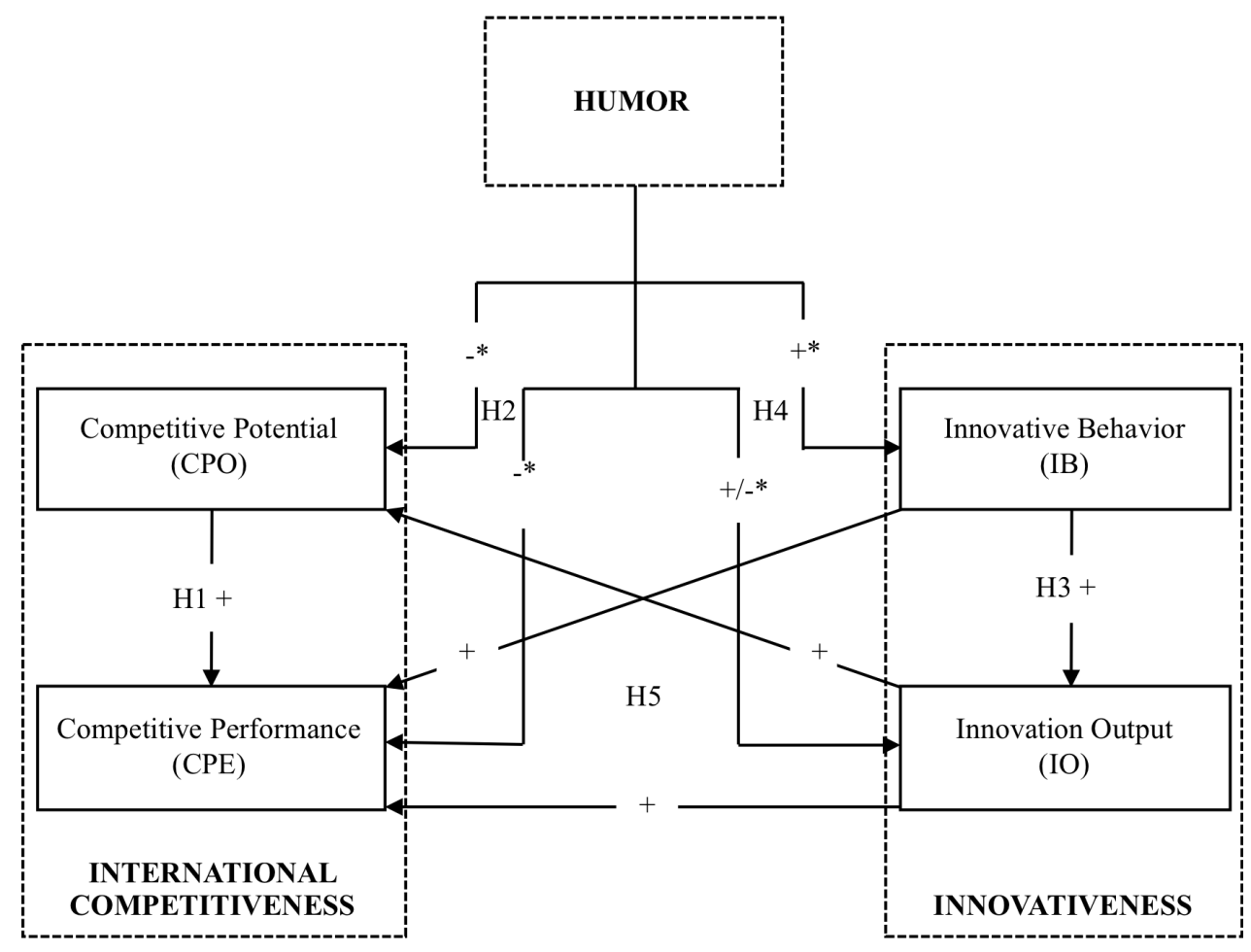

* Table 4 depicts the detailed relationships

Fig. 2. The relationships between humor, international advancements, and innovation processes.

The results of this study suggest that affiliative humor, that can be used to promote interpersonal relationship but increases the difficulty of getting heard in working interactions (Miczo \& Welter, 2006; Rogerson-Revell, 2007), negatively relates to international competitive potential of firms, especially when used with ingroup. This is even more important to acknowledge, as the same, negative, relationship is present considering innovation output that, for its part, is positively related to both dimensions of international competitiveness. The negative connection of affiliative humor and international competitive potential extends the earlier understanding related to the 


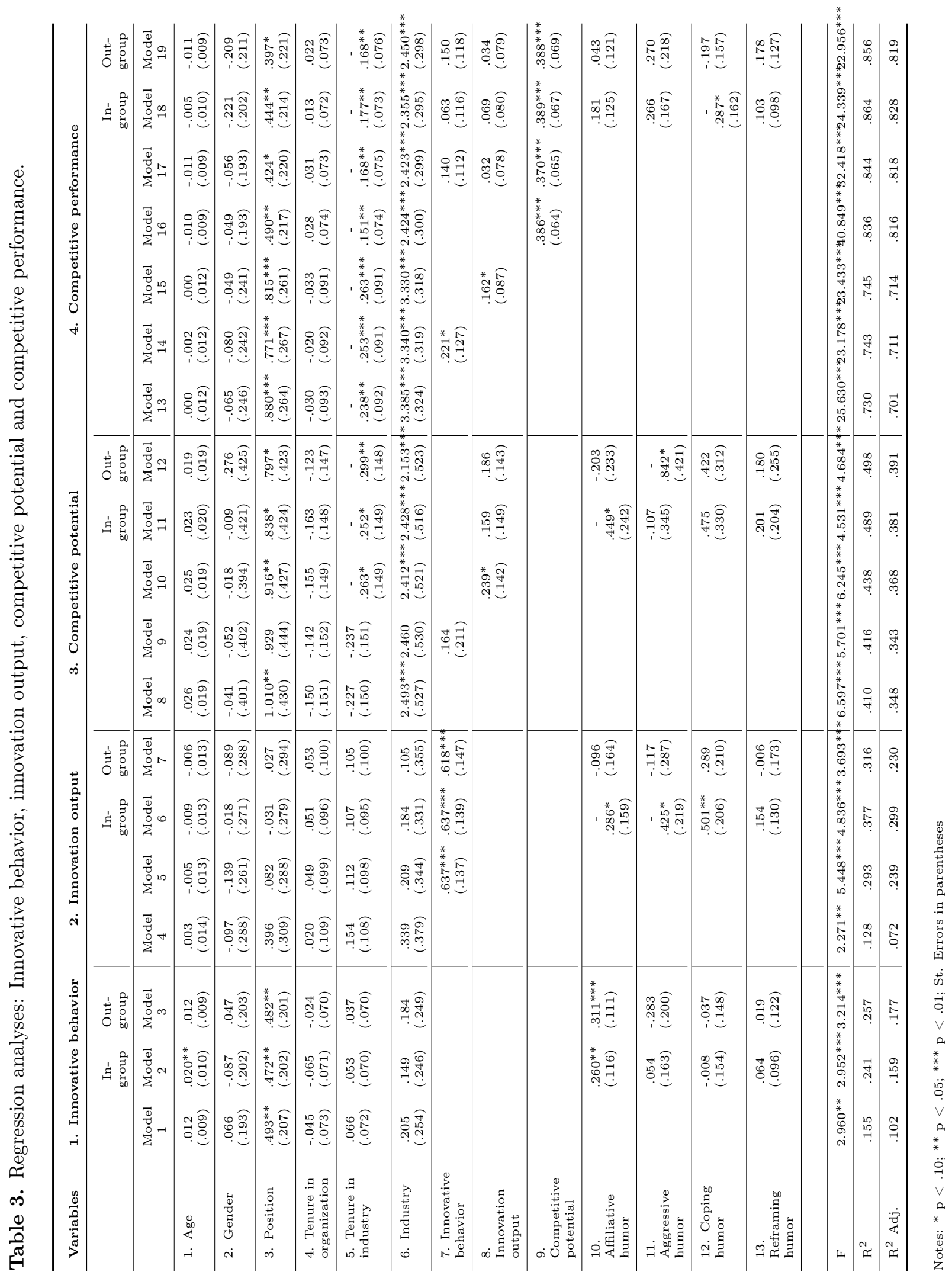


Table 4. Relationships of humor types with competitive potential (CPO), competitive performance (CPE), innovative behavior (IB), and innovation output (IO) for ingroup and outgroup.

\begin{tabular}{|c|c|c|c|c|c|}
\hline "Location" & Humor types & $\mathrm{CPO}$ & $\mathrm{CPE}$ & IB & $\mathrm{IO}$ \\
\hline \multirow{4}{*}{$\begin{array}{l}\text { Within firm } \\
\text { (ingroup) }\end{array}$} & Affiliate humor & - & & + & - \\
\hline & $\begin{array}{l}\text { Aggressive } \\
\text { humor }\end{array}$ & & & & - \\
\hline & Coping humor & & - & & + \\
\hline & $\begin{array}{l}\text { Reframing } \\
\text { humor }\end{array}$ & & & & \\
\hline \multirow{4}{*}{$\begin{array}{l}\text { External relationships } \\
\text { (outgroup) }\end{array}$} & Affiliate humor & & & + & \\
\hline & $\begin{array}{l}\text { Aggressive } \\
\text { humor }\end{array}$ & - & & & \\
\hline & Coping humor & & & & \\
\hline & $\begin{array}{l}\text { Reframing } \\
\text { humor }\end{array}$ & & & & \\
\hline
\end{tabular}

potential of affiliative humor purely enhancing innovative behavior (Hurmelinna-Laukkanen et al., 2016).

We also found that when aggressive humor is used in external relationships, problems emerge in terms of competitive potential. As tension surges and shared commitment drops, the ability of the firm to generate resources and the mutual willingness to share resources will be negatively influenced (Buckley et al., 1988). Thus, the international competitive potential of the firm is harmed. However, when aggressive humor is used with ingroup, international competitiveness does not seem to be influenced. It may be because of the dual role that aggressive humor plays in the workplace: it can hurt relationships or help build cohesive groups (Romero \& Cruthirds, 2006). The findings strengthen further the earlier presented results that aggressive humor seems to be more suitable humor type for firms when it is used in ingroup compared to outgroup relationships (Hurmelinna-Laukkanen et al., 2016).

Interestingly, coping humor used with ingroup shows a significantly negative relationship with international competitive performance. Coping humor is conventionally believed to affect people in a positive way, helping them to psychologically distance from experiencing negative emotions and stressful stimuli (Abel, 2002; Kahn, 1989; Robert \& Wilbanks, 2012). Thus, the negative connection of coping humor and international competitive performance extends the earlier understanding related to the positive findings related to coping humor absolutely enhancing innovative output within firm (Hurmelinna-Laukkanen et al., 2016). A plausible explanation can be found in existing discussions: When international competitiveness is viewed with a coping humor component, it may be rated as less stressful, potentially trivializing the competitiveness and negating valuable reactions (cf. Moran \& Massam, 1999).

Like in the case of international competitiveness, connections of humor and innovativeness are 
somewhat obscure, with sparse studies in real organizational settings (Lehmann-Willenbrock \& Allen, 2014). Our findings indicate that the use of affiliative humor with both ingroup and outgroup boosts innovative behavior. The benevolent joking and making fun of oneself likely enhances an open environment favorable for innovative behavior (Holmes, 2006; Robert \& Wilbanks, 2012). Lyttle (2007), for example, has indicated that thoughtful and responsible use of humor may increase the credibility of an individual in the workplace. However, the influences of affiliative humor on innovative output, as mentioned above, are found to be negative. Our findings provide a more specific look into the different humor types, expanding the findings of Kusumawardani and Wulansari (2018) who have presented that humor, in general, is positively related to innovative outcomes in SME context.

Our findings emphasize generally that humor in its different forms seems to be more prominent when it is used within a firm. This is contradictory compared to Lussier et al. (2017) who found humor to be beneficial for customer relationships. However, they also noted that the effect was short-lived, and they did not specify any humor type. At the same time, our finding is in line with the notion of Rogerson-Revell (2007), who indicates that using humor across firm boundaries may also create a credibility problem. It could be the case in our data.

We also found that use of coping humor with ingroup promotes innovation output. It likely helps people to maintain a positive view to cope with challenges encountered in the innovation process and to finalize the work (Cooper et al., 2018), but when the innovations should be taken to international markets, the role of coping humor changes (as noted above).

On the other hand, when aggressive humor is present within the firm, it negatively influences innovation output (see also Janssen, 2004; Romero \& Cruthirds, 2006). Being negatively judged may make recipients of aggressive humor less likely to bring forth innovation (Huo, Lam, \& Chen, 2012; Yuan \& Woodman, 2010), and the group cohesion may be replaced with competition over resources when the end-results of innovation processes start to form.

The final point is, that since innovativeness and international competitiveness seem connected, apart from competitive potential and innovative behavior, it may be that humor indirectly affects international competitive advancements. The "isolation" between the premises of competitiveness and innovation can actually help firm managers to use humor strategically - differently for different purposes - exploiting the varying effects of different humor types. At the same time, caution needs to be taken in separating the processes in order to avoid a collision. Further research on it is needed, however.

\section{Conclusions}

The above analysis indicates that humor, international competitiveness, and innovativeness are interconnected in intricate ways. Our study contributes especially to the literature of international business management where different ways of increasing international competitiveness and innovativeness have been discussed, including internal and external relationships and communication (e.g. Barnes et al., 2015; Buckley et al., 1990; Eng, 2005). It seems that humor is risky when applied to promote international competitiveness directly, but through enhancing innovation processes and knowledge sharing, the connection between improved innovative potential and output and competitiveness could be used to reach favorable advancements. This finding provi- 
des new insight into the scholarly discussion on the connections between internationalization and innovation, and shows the relevance of acknowledging the distinctions between different steps of the processes in these activities.

The findings also bear managerial relevance. Awareness of different types of humor and their varying roles in international competitiveness and innovation processes enables managers to analyze humor use in their organizations, and support and utilize humor in a purposeful manner (Romero \& Cruthirds, 2006) - avoiding negative outcomes and promoting such connections that yield subsequent benefits for competitiveness. For example, coping humor-making fun or maintaining a humorous attitude to express or allay negative emotions like boredom, anxiety, frustration and anger (Abel, 2002; Kahn, 1989) - can be employed internally to facilitate innovation output. However, this type of humor might have a negative impact when competitive performance is pursued. Managers can set the example in their organizations with their own behavior in using humor, or allowing/denying the use of specific types of humor in different situations. They can monitor humor use, and develop company policies and practices according to what they observe. A real-life practical example is, that in one firm before any meeting, the participants are instructed whether or not to joke with particular clients they are going to meet, and what are the particular issues that cannot be approached with humorous references.

Humor, which is not really very costly, can be a valuable management tool (Cooper et al., 2018) when applied appropriately. What is important to acknowledge, however, is that humor that works in innovation activities - and thereby possibly eventually leads to improved competitiveness - does not necessarily work in international activities, processes, and communication where other aspects than R\&D and innovation are in the focus. Employees could be trained for using humor through group interventions or even online self-administrative interventions (Ruch \& Hofmann, 2017). Nevertheless, further research is needed to investigate more deeply what kind of specific interventions are prominent for contributing to individual performance and/or firm-level competitiveness and innovativeness.

Future studies can benefit from acknowledging the limitations of our study. First, the survey is conducted in a limited amount of organizations, coming originally from a single country. Therefore, the interplay of organizational and national cultures is not accounted for, although these issues may relate to humor use in international settings. Nevertheless, as our findings regarding relationships between innovativeness and competitiveness are similar to those in other studies, we believe that the findings are in line with a wider setting and that our notions extending the discussion to humor are meaningful. Other limitations are shared with most quantitative studies, for example, in terms of research design (cross-sectional rather than longitudinal study), sample size and quality (relatively small sample), measurement (the ability to capture relevant features is always uncertain, even if established measures are used and if thought is put in capturing relevant perceptions at different levels), and limitations with regard to building theory (see Shah \& Corley, 2006); we cannot assert that the emergence of specific types of humor always yield the same results without having a deeper understanding of the mechanisms behind the relationships and interactions. Qualitative approaches are therefore encouraged to provide descriptions of why humor and its specific forms relate to international competitiveness and innovativeness in the way they do, and also provide interpretive frameworks (Van-Maanen, 1979). 
Here, we have explored and found some patterns that hopefully provide some direction for subsequent research.

\section{References}

Abel, M. H. (2002). Humor, stress, and coping strategies. International Journal of Humor Research, 4 (2002), 365-381.

Alvarez, H., \& Iske, P. (2015). Internal Capabilities and External Knowledge Sourcing for Product Innovation in LMT SMEs. Journal of Innovation Management, 3(2), 55-70.

Andries, P., \& Czarnitzki, D. (2014). Small firm innovation performance and employee involvement. Small Business Economics, 43(1), 21-38.

Armstrong, J. S., \& Overton, T. S. (1977). Estimating Nonresponse Bias in Mail Surveys. Journal of Marketing Research, 14 (3), 396-402.

Barczak, G., Lassk, F., \& Mulki, J. (2010). Antecedents of Team Creativity: An Examination of Team Emotional Intelligence, Team Trust and Collaborative Culture. Creativity and Innovation Management, 19(4), 332-345.

Barnes, B. R., Leonidou, L. C., Siu, N. Y. M., \& Leonidou, C. N. (2015). Interpersonal Factors as Drivers of Quality and Performance in Western-Hong Kong Interorganizational Business Relationships. Journal of International Marketing, 23(1), 23-49.

Barroso-Tanoira, F. G. (2017). Motivation for increasing creativity, innovation and entrepreneurship. An experience from the classroom to business firms. Journal of Innovation Management, 5(3), 55-74.

Bartel, C. A., \& Garud, R. (2009). The Role of Narratives in Sustaining Organizational Innovation. Organization Science, 20(1), 107-117.

Bhawsar, P., \& Chattopadhyay, U. (2015). Competitiveness: Review, Reflections and Directions. Global Business Review, 16(4), 665-679.

Brännback, M., \& Wiklund, P. (2001). A new dominant logic and its implications for knowledge management: a study of the Finnish food industry. Knowledge and Process Management, 8(4), 197-206.

Buckley, P. J., Pass, C. L., \& Prescott, K. (1988). Measures of international competitiveness: A critical survey. Journal of Marketing Management, 4(2), 175-200.

Buckley, P. J., Pass, C. L., \& Prescott, K. (1990). Measures of international competitiveness: Empirical findings from British manufacturing companies. Journal of Marketing Management, $6(1), 1-13$.

Buesa, M., \& Molero, J. (1998). La regularidad innovadora en empresas españolas. Revista de Economía Aplicada, Vol. 6(No 17), 111-134. Access April 2019:

http://dialnet.unirioja.es/servlet/articulo?codigo $=176802$

Caloghirou, Y., Kastelli, I., \& Tsakanikas, A. (2004). Internal capabilities and external kno- 
wledge sources: Complements or substitutes for innovative performance? Technovation, 24(1), $29-39$.

Carmeli, A., \& Spreitzer, G. M. (2009). Trust, Connectivity, and Thriving: Implications for Innovative Behaviors at Work. The Journal of Creative Behavior, 43(3), 169-191.

Castellacci, F. (2008). Technological paradigms, regimes and trajectories: Manufacturing and service industries in a new taxonomy of sectoral patterns of innovation. Research Policy, 37(6-7), 978-994.

Cetindamar, D., \& Kilitcioglu, H. (2013). Measuring the competitiveness of a firm for an award system. Competitiveness Review, 23(1), 7-22.

Chikán, A. (2008). National and firm competitiveness: a general research model. Competitiveness Review, 18(1/2), 20-28.

Cleveland, M., Laroche, M., \& Papadopoulos, N. (2015). You are what you speak? Globalization, multilingualism, consumer dispositions and consumption. Journal of Business Research, 68(3), $542-552$.

Cooper, C. (2008). Elucidating the bonds of workplace humor: A relational process model. Human Relations, 61 (8), 1087-1115.

Cooper, C. D. (2005). Just joking around? employee humor expression as an ingratiatory behavior. Academy of Management Review, 30(4), 765-776.

Cooper, C. D., Kong, D. T., \& Crossley, C. D. (2018). Leader Humor as an Interpersonal Resource: Integrating Three Theoretical Perspectives. Academy of Management Journal, 61(2), 769-796.

Damanpour, F., \& Gopalakrishnan, S. (1998). Theories of organizational structure and innovation adoption: the role of environmental change. Journal of Engineering and Technology Management, 15(1), 1-24.

de Jong, J., \& den Hartog, D. (2010). Measuring Innovative Work Behaviour. Creativity and Innovation Management, 19(1), 23-36.

Dey, T., \& Mukhopadhyay, S. (2018). Linkage between contextual factors, knowledge-sharing mediums, and behaviour: Moderating effect of knowledge-sharing intentions. Knowledge and Process Management, 25(1), 31-40.

Dorenbosch, L., van Engen, M. L., \& Verhagan, M. (2005). On-the-job Innovation: The Impact of Job Design and Human Resource Management through Production Ownership. Creativity and Innovation Management, 14 (2), 129-141.

Eng, T.-Y. (2005). The Effects of Learning on Relationship Value in a Business Network Context. Journal of Business-to-Business Marketing, 12(4), 67-101.

Ferreira, J. J. P., Mention, A.-L., \& Torkkeli, M. (2015). Illumination in times of Uncertainty: Fifty Shades of Innovation for Societal Impact. Journal of Innovation Management, $3(1), 1-4$. 
Galende, J., \& De La Fuente, J. M. (2003). Internal factors determining a firm's innovative behaviour. Research Policy, 32(5), 715-736.

Graham, E. E. (1995). The Involvement of Sense of Humor in the Development of Social Relationships. Communication Reports, 8(2), 158-169.

Hair, J. F., Anderson, R. E., Tatham, R. L., \& Black, W. C. (1998). Multivariate data analysis with readings ( $5 n d$ ed.). New Jersey: Prentice Hall.

Hassan, R., Razek, A.-, \& Alharbi, F. B. (2017). Assessment of Technological Innovation Climate in Organizations. Journal of Innovation Management, 5(3), 34-54.

Holmes, J. (2006). Sharing a laugh: Pragmatic aspects of humor and gender in the workplace. Journal of Pragmatics, 38 (1 SPEC. ISS.), 26-50.

Huo, Y., Lam, W., \& Chen, Z. (2012). Am I the Only One This Supervisor is Laughing at? Effects of Aggressive Humor on Employee Strain and Addictive Behaviors. Personnel Psychology, 65(4), 859-885.

Hurmelinna-Laukkanen, P., Atta-Owusu, K., \& Oikarinen, E.-L. (2016). You are joking right? - connecting humor types to innovative behavior and innovation output. International Journal of Innovation Management, 20 (08), 1640021.

Hurmelinna-Laukkanen, P., \& Ritala, P. (2012). Appropriability as the driver of internationalization of service-oriented firms. The Service Industries Journal, 32(7), 1039-1056.

Janssen, O. (2004). How fairness perceptions make innovative behavior more or less stressful. Journal of Organizational Behavior, 25(2), 201-215.

Jones, G. E., \& Bear, S. E. (2018). Gender Differences and Perceived Efficacy of Humor Styles in the Workplace. In Emerging Challenges in Business, Optimization, Technology, and Industry (pp. 199-203). Springer, Cham.

Kafouros, M. I., Buckley, P. J., Sharp, J. A., \& Wang, C. (2008). The role of internationalization in explaining innovation performance. Technovation, 28(1-2), 63-74.

Kahn, W. A. (1989). Toward a Sense of Organizational Humor: Implications for Organizational Diagnosis and Change. The Journal of Applied Behavioral Science, 25(1), 45-63.

Kakar, A. K. (2018). How do team cohesion and psychological safety impact knowledge sharing in software development projects? Knowledge and Process Management, 25 (4), 258-267.

Keogh, W. (1999). Understanding processes and adding value within innovative small firms. Knowledge and Process Management, 6(2), 114-125.

Kesting, P., \& Parm Ulh $\varnothing$, J. (2010). Employee-driven innovation: extending the license to foster innovation. Management Decision, 48(1), 65-84.

Kodama, M. (2017). Developing strategic innovation in large corporations-The dynamic capability view of the firm. Knowledge and Process Management, 24 (4), 221-246.

Kotro, T., \& Pantzar, M. (2002). Product Development and Changing Cultural Landscapes - Is Our Future in "Snowboarding"? Design Issues, 18(2), 30-45. 
Kuiper, N. A., McKenzie, S. D., \& Belanger, K. A. (1995). Cognitive appraisals and individual differences in sense of humor: Motivational and affective implications. Personality and Individual Differences, 19(3), 359-372.

Kusumawardani, D., \& Wulansari, N. A. (2018). The effect of humor and narcissistic personality on the innovative output with innovative work behavior and adaptability as variables of mediation. Management Analysis Journal, 7(3), 352-362.

Lang, J. C., \& Lee, C. H. (2010). Workplace humor and organizational creativity. International Journal of Human Resource Management, 21(1), 46-60.

Lehmann-Willenbrock, N., \& Allen, J. A. (2014). How fun are your meetings? Investigating the relationship between humor patterns in team interactions and team performance. Journal of Applied Psychology, 99(6), 1278-1287.

Lussier, B., Grégoire, Y., \& Vachon, M.-A. (2017). The role of humor usage on creativity, trust and performance in business relationships: An analysis of the salesperson-customer dyad. Industrial Marketing Management, 65, 168-181.

Lyttle, J. (2007). The judicious use and management of humor in the workplace. Business Horizons, 50(3), 239-245.

Malone, P. B. (1980). Humor: A Double-Edged Tool for Today's Managers? The Academy of Management Review, 5(3), 357.

Martin, R. A., Puhlik-Doris, P., Larsen, G., Gray, J., \& Weir, K. (2003). Individual differences in uses of humor and their relation to psychological well-being: Development of the humor styles questionnaire. Journal of Research in Personality, 37(1), 48-75.

Maskus, K. E. (2008). The Globalization of Intellectual Property Rights and Innovation in Services. Journal of Industry, Competition and Trade, 8(3-4), 247-267.

Mcfadzean, E. (1998). Enhancing creative thinking within organisations. Management Decision, 36(5), 309-315.

Mesmer-Magnus, J., Glew, D. J., \& Viswesvaran, C. (2012). A meta-analysis of positive humor in the workplace. Journal of Managerial Psychology, 27(2), 155-190.

Miczo, N., \& Welter, R. E. (2006). Aggressive and Affiliative Humor: Relationships to Aspects of Intercultural Communication. Journal of Intercultural Communication Research, 35(1), $61-77$.

Moran, C. C., \& Massam, M. M. (1999). Differential Influences of Coping Humor and Humor Bias on Mood. Behavioral Medicine, 25(1), 36-42.

Ng, T. W. H., \& Feldman, D. C. (2013). A meta-analysis of the relationships of age and tenure with innovation-related behaviour. Journal of Occupational and Organizational Psychology, $86(4), 585-616$.

Ohlott, P. J., Ruderman, M. N., \& Mccauley, C. D. (1994). Gender Differences in Managers' Developmental Job Experiences. Management Journal, 37(1), 46-67. 
Oura, M. M., Zilber, S. N., \& Lopes, E. L. (2016). Innovation capacity, international experience and export performance of SMEs in Brazil. International Business Review, 25 (4), 921-932.

Özçelik, E., \& Taymaz, E. (2004). Does innovativeness matter for international competitiveness in developing countries?: The case of Turkish manufacturing industries. Research Policy, 33(3), 409-424.

Pascucci, F. (2018). The export competitiveness of Italian coffee roasting industry. British Food Journal, 120(7), 1529-1546.

Peneder, M., \& Rammer, C. (2018). Measuring Competitiveness. ZEW-Gutachten und Forschungsberichte.

Perry-Smith, J. E., \& Shalley, C. E. (2003). The social side of creativity: A static and dynamic social network perspective. The Academy of Management Review, 28(1), 89-106.

Podmetina, D., \& Smirnova, M. (2013). R\&D Cooperation with External Partners and Implementing Open Innovation. Journal of Innovation Management, 1(2), 103-124.

Podsakoff, P. M., MacKenzie, S. B., Lee, J. Y., \& Podsakoff, N. P. (2003). Common method biases in behavioral research: a critical review of the literature and recommended remedies. Journal of Applied Psychology, 88(5), 879-903.

Prajogo, D. I., \& Ahmed, P. K. (2006). Relationships between innovation stimulus, innovation capacity, and innovation performance. $R$ and D Management, 36(5), 499-515.

Ramamoorthy, N., Flood, P. C., Slattery, T., \& Sardessai, R. (2005). Determinants of Innovative Work Behaviour: Development and Test of an Integrated Model. Creativity and Innovation Management, 14 (2), 142-150.

Robert, C., \& Wilbanks, J. E. (2012). The Wheel Model of humor: Humor events and affect in organizations. Human Relations, 65 (9), 1071-1099.

Rogerson-Revell, P. (2007). Humour in business: A double-edged sword. A study of humour and style shifting in intercultural business meetings. Journal of Pragmatics, 39(1), 4-28.

Romero, E. J., \& Cruthirds, K. W. (2006). The Use of Humor in the Workplace. Academy of Management Perspectives, 20(2), 58-69.

Romero, E., \& Pescosolido, A. (2008). Humor and group effectiveness. Human Relations, 61 (3), $395-418$.

Ruch, W., \& Hofmann, J. (2017). Fostering Humour. In C. Proctor (Ed.), Positive Psychology Interventions in Practice, (pp. 65-80). Cham: Springer.

Scott, S. G., \& Bruce, R. A. (1994). Determinants of innovative behaviour: A path model of individual innovation in the workplace. Academy of Management Journal, 37(3), 580-607.

Shah, S. K., \& Corley, K. G. (2006). Building Better Theory by Bridging the Quantitative Qualitative Divide. Journal of Management Studies, Volume 43(8), 1821-1835.

Skoric, M. M., \& Park, Y. J. (2014). Culture, technologies and democracy: A cross-national analysis of political development. Telematics and Informatics, 31(3), 364-375. 
Tajfel, H. (1982). Social Psychology of Intergroup Relations. Annual Review of Psychology, $33(1), 1-39$.

Unsworth, K. L., \& Parker, S. K. (2003). Proactivity and innovation: Promoting a new workforce for the new workplace. In D. Holman, T. D. Wall, C. W. Clegg, P. Sparrow, \& A. Howard (Eds.), The New Workplace: A Guide to the Human Impact of Modern Working Practices (pp. 175-196). Chichester, England: Wiley.

Van-Maanen, J. (1979). Reclaiming Qualitative Methods for Organizational Research: A Preface. Administrative Science Quarterly, 24(4), 520-524.

Vance, C. M. (2005). The personal quest for building global competence: A taxonomy of selfinitiating career path strategies for gaining business experience abroad. Journal of World Business, 40(4), 374-385.

Yuan, F., \& Woodman, R. W. (2010). Innovative Behavior in the Workplace: The Role of Performance and Image Outcome Expectations. Academy of Management Journal, 53(2), 323-342. 


\section{Appendix 1: Explanation of variables.}

\begin{tabular}{|c|c|}
\hline Variables & Explanation \\
\hline Age & The age of respondents \\
\hline Gender & Dummy variable: 1 if respondent is male, 0 if respondent is female \\
\hline Position & $\begin{array}{l}\text { Dummy variable: } 1 \text { if respondent is in managerial position, } 0 \text { if } \\
\text { respondent is not }\end{array}$ \\
\hline $\begin{array}{l}\text { Tenure in } \\
\text { organization }\end{array}$ & How long have you been working in this organization? \\
\hline $\begin{array}{l}\text { Tenure in } \\
\text { industry }\end{array}$ & How long have you been working in this industry? \\
\hline Industry & $\begin{array}{l}\text { Dummy variable: } 1 \text { if organization works in manufacturing industry, } 0 \text { if } \\
\text { organization does not }\end{array}$ \\
\hline Affiliative humor* & $\begin{array}{l}\text { Five-point Likert scale; } \\
\text { 1. I usually joke around much with people } \\
\text { 2. I usually like to tell jokes and amusing stories to others } \\
\text { 3. I enjoy making people laugh } \\
\text { 4. I usually think of witty things to say when I'm with other people } \\
\text { 5. I make other people laugh by telling funny stories about myself }\end{array}$ \\
\hline $\begin{array}{l}\text { Aggressive } \\
\text { humor* }\end{array}$ & $\begin{array}{l}\text { Five-point Likert scale; } \\
\text { 1. If I don't like someone, I often use humor or teasing to put them } \\
\text { down } \\
\text { 2. If something is really funny to me, I will laugh or joke about it even } \\
\text { if someone will be offended } \\
\text { 3. If someone makes a mistake, I will often tease them about it } \\
\text { 4. I like it when people use humor as a way of criticizing or putting } \\
\text { something down } \\
\text { 5. I participate in laughing at others if everyone is doing it }\end{array}$ \\
\hline Coping humor* & $\begin{array}{l}\text { Five-point Likert scale; } \\
\text { 1. Frequent laughter is used to make work more pleasant } \\
\text { 2. Funny stories are always told to brighten up a bad day with a good } \\
\text { laugh } \\
\text { 3. Sensitive organizational issues are usually handled by joking about } \\
\text { them } \\
\text { 4. Funny stories and jokes are welcome in most meetings } \\
\text { 5. Humorous stories help to ease tension situations } \\
\text { 6. Jokes are frequently shared to loosen up a stressful work environment } \\
\text { 7. Silly jokes or ridiculous stories are rarely heard }\end{array}$ \\
\hline
\end{tabular}




\begin{tabular}{|c|c|}
\hline Variables & Explanation \\
\hline $\begin{array}{l}\text { Reframing } \\
\text { humor* }\end{array}$ & $\begin{array}{l}\text { Five-point Likert scale; } \\
\text { 1. Silly jokes are used to question old mindsets and practices } \\
\text { 2. Counter-intuitive jokes are encouraged to help us see things in new } \\
\text { light } \\
\text { 3. Funny stories and jokes that help us see old problems in new light } \\
\text { are common }\end{array}$ \\
\hline $\begin{array}{l}\text { Innovative } \\
\text { behavior }\end{array}$ & $\begin{array}{l}\text { Five-point Likert scale; } \\
\text { 1. I often generate original solutions for problems } \\
\text { 2. I often pay attention to issues that are not part of my daily work } \\
\text { 3. I often strive to convince people to support an innovative idea } \\
\text { 4. I often contribute to the implementation of new ideas } \\
\text { 5. I often search out new working methods, techniques, or instruments } \\
\text { 6. I often make important organizational members enthusiastic for } \\
\text { innovative ideas } \\
\text { 7. I often see how things can be improved } \\
\text { 8. I often systematically introduce innovative ideas into work practices } \\
\text { 9. I often put effort in the development of new things } \\
\text { 10. I often find new approaches to execute tasks. }\end{array}$ \\
\hline Innovation output & $\begin{array}{l}\text { Five-point Likert scale; } \\
\text { 1. Implementation of completely new production or delivery } \\
\text { methods/techniques } \\
\text { 2. Implementation of new ways of organizing relations with external } \\
\text { stakeholders } \\
\text { 3. Implementation of new methods of organizing work responsibilities } \\
\text { and decision making } \\
\text { 4. Improvement in current production or delivery methods/techniques } \\
\text { 5. Improvement of current products/services } \\
\text { 6. Significant changes to the design or packaging of products/services } \\
\text { 7. Development of completely new products/services. } \\
\text { 8. Implementation of new methods for marketing products/services } \\
\text { 9. Implementation of new methods for organizing routines/procedures }\end{array}$ \\
\hline $\begin{array}{l}\text { Competitive } \\
\text { potential }\end{array}$ & $\begin{array}{l}\text { Five-point Likert scale; } \\
\text { 1. Quality of products/services on international markets } \\
\text { 2. Development of new products/services with international business } \\
\text { partners } \\
\text { 3. Satisfaction of international customers/clients } \\
\text { 4. Ability to attract new customers/clients from other countries } \\
\text { 5. Development of brand or corporate image on international markets } \\
\text { 6. Development of international know-how }\end{array}$ \\
\hline
\end{tabular}




\begin{tabular}{ll}
\hline Variables & Explanation \\
\hline Competitive & Five-point Likert scale; \\
1. Werformance collaborate with organizations from other countries \\
2. Our products/services are patronized by customers/clients from \\
other countries \\
3. We actively seek for customers/clients from other countries \\
4. Our foreign sales contribute a significant percentage of total sales \\
5. We perform key aspects of our operations in other countries \\
6. Employees spend significant part of their time on international \\
activities \\
7. Ability to gain market access in other countries \\
8. International sales volume \\
9. International market share \\
10. International profitability \\
* Use asked in relation to Ingroup (Information provided to the \\
respondents in the questionnaire is as follows: Immediate Co-workers; \\
"Refers to your co-workers who are members of your workgroup or \\
team" - cf. Other Co-workers; "Refers to your co-workers who are NOT \\
members of your workgroup or team"), and Outgroup (External \\
relations; "Refers to outside actors (e.g. customers, suppliers, other \\
stakeholders) who have a business relationship with your organization"). \\
Note: Original scales were relied on to a large extent to maintain some \\
comparability with earlier studies; at the same time, individual and \\
organizational views were pursued simultaneously by instructing \\
respondents and top-managers answering the questionnaire. Aggregated \\
perceptions of the individual respondents for each firm were also \\
reflected to public information on the respective organization's \\
innovation and international activity to verify that individual \\
perceptions matched the actual situation to an adequate extent. \\
\end{tabular}




\section{Biographies}

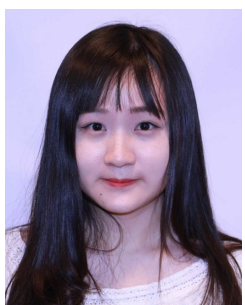

Jialei Yang. Jialei Yang received her M.Sc. degree in economics and business administration from University of Oulu, Finland (got full marks for her master's thesis), and the B.Ec. degree in international trade and economics from Jiangxi University of Finance \& Economics, China (ranked 1st among 180 students in the program). She is currently pursuing the Ph.D degree in economics and business administration (management) at Oulu Business School, University of Oulu, Finland. Her research interests include innovation management, international business, and network management. Mrs. Yang's awards and honors include Outstanding Undergraduate (Chinese Scholarship Council), the Provincial Silver Medal in Science and Technology Innovation and Vocational Skills Demonstration (Competition) and Pacemaker to Merit Student (JUFE).

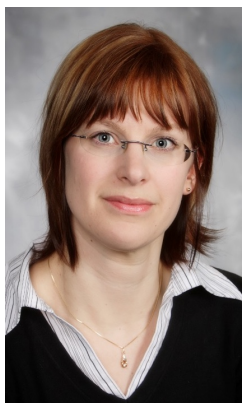

Pia Hurmelinna-Laukkanen. Dr. Pia Hurmelinna is a Professor of Marketing, especially International Business at the Oulu Business School, University of Oulu, and an Adjunct Professor (Knowledge Management) at the Lappeenranta University of Technology, School of Business and Management. She has published about 70 refereed articles in journals such as Journal of Product Innovation Management, Industrial and Corporate Change, Industrial Marketing Management, International Business Review, R\&D Management, and Technovation. She has contributed to book chapters, over 140 conference papers, and other scientific and managerial publications. She is a member of editorial boards of Industrial Marketing Management, Journal of Innovation Management, Journal of Service Management, and ISPIM scientific panel. She also has been serving as a quest editor and a reviewer for many journals and conferences. Most of her research has involved innovation management and appropriability issues, including examination of different knowledge protection and value capturing mechanisms. The research covers varying contexts like internationalization and inter-organizational collaboration.

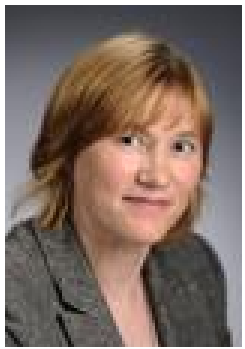

Eeva-Liisa Oikarinen. Eeva-Liisa Oikarinen received the M.Sc. in Biophysics from University of Oulu, Finland, in 2002, and Ph.D. degree (Econ. \& Bus. Adm.) in Marketing from Oulu Business School, University of Oulu, in 2018. Since 2018, she has been an Assistant Professor in Marketing at Oulu Business School. She is the author of more than 50 publications. Her research has been focused on human aspects such as: humor, storytelling, and emotions, in business interactions. Currently, her main research interest is focused on recruitment advertising, wellbeing and ethics, digital marketing and human-robot service interactions. She has published in Journal of Service Management, Journal of Retailing and Consumer Services, International Journal of Innovation Management, Corporate Reputation Review, and Australasian Marketing Journal, among others. Dr. Oikarinen received Outstanding Elsevier Reviewer Recognition in Journal of Retailing and Consumer Services in October 2018 and she was a recipient of The 5th Nordic Retail and Wholesale Conference (NRWC2016) best paper award.

\section{ISSN 2183-0606}

http://www.open-jim.org

http://creativecommons.org/licenses/by/3.0 